\title{
PENGARUH RELIGIUSITAS DAN DUKUNGAN SOSIAL TERHA- DAP KUALITAS HIDUP PENDERITA KANKER SERVIKS
}

\author{
Megawaty \\ egapsikologi91@gmail.com \\ Fakultas Psikologi UIN Syarifhidayatullah Jakarta
}

\begin{abstract}
The results showed that there was a significant effect of variables religiosity and social support on quality of life. The test results were minor hypothesis test the significance of each dimension of the independent variable on quality of life, there are three significant regression coefficients, including experience, conviction and consequences. The results showed the proportion of the variance of quality of life for all the independent variables explained $31.6 \%$ and $68.4 \%$ is influenced by other variables outside the research.
\end{abstract}

Keyword : Quality of life, religiousity and social support. 


\section{Pendahuluan}

Dari data yang telah ditemukan dinyatakan bahwa angka kematian tertinggi akibat kanker serviks banyak dijumpai di negara-negara asia tenggara salah satunya adalah Indonesia (WHO,2013 b). Oleh karena itu, negara-negara berkembang seperti negara di Asia Tenggara perlu menjadi sorotan utama untuk menekan angka laju pertumbuhan kasus kanker serviks khususnya Negara Indonesia.

Pada umumnya perempuan lebih berisiko mengalami kanker serviks dan penyakit ini terjadi pada perempuan berusia aktif seksual (Kemenkes, 2008). Pada usia aktif seksual ini biasanya dapat dijumpai pada usia pertengahan (Middle-Years)pada usia 40-60 tahun dan pada perempuan yang telah menikah (Goker et al., 2011).

Pada umumnya sebagian perempuan dalam kondisi menderita kanker serviks akan merasa pada periode krisis sehingga membutuhkan penyesuaian. Dan pada setiap penderita akan membutuhkan penyesuaian yang berbeda tergantung pada persepsi, sikap serta pengalaman pribadinya (Fitriana \& Ambarini, 2012). Dalam persepsi yang berbeda-beda terhadap penyesuaian dirinya ketika menderita kanker serviks, kualitas hidup yang tinggi akan menjadi hal yang penting yang mampu membuat persepsi penderita kanker serviks tentang hidup menjadi meningkat dan hal ini sangat dibutuhkan bagi penderita kanker serviks guna mempengaruhi hidupnya serta lingkungan sosialnya (Goker et al., 2011).

Berdasarkan penelitian yang telah dipaparkan tersebut, peneliti merasa perlu untuk melakukan penelitian tentang pengaruh kualitas hidup, religiusitas dan dukungan sosial. Karena variabel-varibel tersebut memiliki peran penting bagi penderita kanker serviks terhadap kehidupanya.

Pada penilitian Zeng et al. (2010) telah ditemukan bahwa penderita kanker serviks di China memiliki persepsi terhadap hidup yang baik dan hal itu yang membuat kuialitas hidupnya menjadi baik pula. Sehingga ia bisa menyesuaikan hidupnya melewati masa krisis dalam hidupnya. Kualitas hidup yang didapatkannya diperoleh dari status sosial ekonomi yang baik, aspek spiritualitas ataupun religiusitas yang baik dan dukungan sosial yang baik pula.

Aukust et al. (2009) juga melakukan penelitian tentang kanker payudara yang mengaitkan pada variabel religuisitas selain dia melakukan penelitian dengan variabel kualitas hidup. Dalam penelitianya di ungkapkanbahwa tingkat religiusitas yang tinggi mampu mempengaruhi 
kualitas hidup dan persepsi kesehatan penderita kanker payudara menjadi meningkat, mereka lebih dapat menerima kondisinya dan memiliki persepsi yang baik.

Penelitian lainnya yang juga memiliki hasil sama adalah penelitian Lim dan Wi (2009) yang juga menunjukkan variabel religiusitas mempengaruhi kualitas hidup penderita kanker payudara sehingga meningkatkan proses kesembuhannya.

Selain variabel religiusitas, variabel dukungan sosial juga menjadi sebuah variabel penting yang dapat mempengaruhi kualitas hidup seseorang penderita penyakit berat seperti kanker. Dukungan sosial memberi kontribusi penting yang berhubungan dengan religiusitas dan kualitas hidup (Lim \& Wi, 2009).

Kualitas hidup menurut WHO(1998) adalah persepsi individu terhadap posisi hidupnya dalam konteks kebudayaan, sistem nilai dimana berhubungan dengan tujuan, ekspektasi Dalam persepsi

yang berbeda-beda terhadap penyesuaian diri penderita kanker serviks, kualitas hidup yang tinggi akan menjadi hal yang penting yang mampu membuat persepsi penderita kanker serviks tentang hidup menjadi meningkat dan hal ini sangat dibutuhkan bagi penderita kanker serviks guna mempengaruhi hidupnya serta lingkungan sosialnya (Goker et al., 2011).

Menurut Glock \& Stark religiusitas merupakan aktifitas keberagamaan seseorang yang diwujudkan dalam ritual maupun aktifitas supranatural seseorang dan diidentifikasikan ke dalam lima dimensi keberagamaan yakni Memiliki kepercayaan atau ideologi terhadap agamanya (Religious Belief), melakukan praktik dalam agamanya / ibadah ( Religious Practice, Memiliki pengalaman beragama (experience religious),memiliki pengetahuan tentang agamanya (Religious Knowledge), mampu melakukan pengamalan terhadap praktik ibadahnya (Religious Consequensional) (Stark \& Glock, 1974).

Dalam hal ini Jurnal penelitian yang membahas mengenai religiusitas mempengaruhi kualitas hidup penderita kanker serviks terdapat dalam penelitian dan standart hidupnya. Berhubungan dengan status kesehatan fisik, status psikologis, tingkat kemandirian, hubungan sosial, keyakinan individu, dan hubungannya dengan lingkungan.

Zeng et al. (2010) yang mengemukakan bahwa penderita kanker serviks di China mengalami kualitas hidup yang baik dikarenakan pengaruh 
religiusitas yang baik pula pada penderita kanker serviks tersebut.

Dukungan sosial adalah sebuah dukungan berupa kepedulian yang ditunjukkan dengan dukungan emosional, penghargaan, perhatian, dukungan instrumental dan dukungan informasi serta jaringan kepada orang yang membutuhkan dukungan tersebut dan didapat dari orang- orang serta lingkungan sekitar.

Weiss (1974) mendeskripsikan enam ketetapan fungsi sosial yang berbeda yang diperoleh dari hubungan antara yang satu dengan yang lainnya. Enam dari ketetapan tersebut membutuhkan individu untuk merasakan kesamaan untuk saling mendukung dan menghindari kesendirian. Enam ketetapan fungsi sosial menurut Weiss terdiri dari Attachment (Kedekatan emosional), Social Integration (Integrasi sosial), Reassurance of Worth (Penghargaan/Pengakuan), Relliable Alliance (Ikatan yang dapat diandalkan), Guidance (Bimbingan), Opportunity of Nurturance (Kemungkinan membantu).

Dalam hal ini Jurnal penelitian yang membahas mengenai dukungan sosial mempengaruhi kualitas hidup penderita kanker serviks terdapat dalam penelitian Zeng et al. (2010) yang mengemukakan bahwa penderita kanker serviks di China mengalami kualitas hidup yang baik dikarenakan pengaruh dukungan sosial yang baik pula pada penderita.

\section{Metode Penelitian}

Populasi dalam penelitian ini adalah penderita kanker serviks stadium I-IV yang berobat rawat jalan dan tercatat di RSCM sebanyak 130 penderita kanker serviks. Teknik sampling yang akan digunakan dalam penelitian ini adalah non probability sampling dimana tidak semua anggota populasi memiliki kesempatan yang sama. Sedangkan skala yang digunakan dalam penelitian ini ada tiga skala yaitu WHO Qol Breef, skala religiusitas dan skala dukungan sosial.

\section{WHO Qol Breff}

Kualitas Hidup yang diambil dari sekian banyaknya jenis skala kualitas hidup yang dimiliki oleh WHO. Skala tersebut adalah WHOQOL-BREFF (WHO, 1998). Skala ini memiliki lima aspek yaitu : fisik, psikologi, kemandirian, hubungan sosial dan hubungan lingkungan. Setelah dilakukan uji validitas konstruk dengan menggunakan Confirmatory Factor Analysis (CFA) diperoleh model fit dengan chi-square $==206.98$, $\mathrm{df}=185$ dan $\mathrm{p}$ value $=0.12822$, RSMEA $=0.030$. 
2. Skala Religiusitas

Religiusitas diukur dengan menggunakan skala yang diadaptasi dari Skala Religiusitas Glock \& Stark (1974). Skala ini memiliki lima dimensi, yaitu : keyakinan beragama, praktik ibadah, pengalaman beragama, pengetahuan beragama dan konsekuensi beragama.

- Setelah dilakukan uji validitas konstruk keyakinan beragama dengan menggunakan Confirmatory Factor Analysis (CFA) diperoleh model fit dengan chi-square $==1.36$, $\mathrm{df}=1 \mathrm{dan} \mathrm{p}$ value $==0.24406$, $\mathrm{RSMEA}=0.053$.

- Setelah dilakukan uji validitas konstruk praktik ibadah dengan menggunakan Confirmatory Factor Analysis (CFA) diperoleh model fit dengan chi-square $==0.00, \mathrm{df}=0$ dan $\mathrm{p}$-value $==$ 1.00000, RSMEA $=0.000$.

- Setelah dilakukan uji validitas konstruk pengalaman beragama dengan menggunakan Confirmatory Factor Analysis (CFA) diperoleh model fit dengan chi-square $==1.23, \mathrm{df}=3$ dan $\mathrm{p}$ - value $==0.74501$, RSMEA $=0.000$.

- Setelah dilakukan uji validitas konstruk pengetahuan beragama dengan menggunakan Confirmatory Factor Analysis (CFA) diperoleh model fit dengan chi-square $==0.000, \mathrm{df}=1 \mathrm{dan} \mathrm{p}$ value $==1.00000$, RSMEA $=0.000$.

- Setelah dilakukan uji validitas konstruk konsekuensi beragama dengan menggunakan Confirmatory Factor Analysis (CFA) diperoleh model fit dengan chi-square $=0.000, \mathrm{df}=1 \mathrm{dan} p$ value $==1.00000$, RSMEA $=0.000$.

\section{Skala Dukungan Sosial}

Skala Dukungan Sosial diukur dengan menggunakan skala yang diadaptasi dari Skala yang telah dikembangkan oleh Russell (1974). Skala ini memiliki enam dimensi, yaitu : Bimbingan, penghargaan, integrasi sosial, kedekatan emosional, ikatan yang dapat diandalkan dan kemungkinan membantu.

- Setelah dilakukan uji validitas konstruk bimbingan dengan menggunakan Confirmatory Factor Analysis (CFA) diperoleh model fit dengan chi-square $==0.00, \mathrm{df}=0$ dan $\mathrm{p}$-value $==$ 1.00000 , RSMEA $=0.000$.

- Setelah dilakukan uji validitas konstruk penghargaan dengan menggunakan Confirmatory Factor Analysis (CFA) diperoleh 
model fit dengan chi-square $==0.00, \mathrm{df}=0$ dan $\mathrm{p}$-value $==$ 1.00000 , RSMEA $=0.000$.

- Setelah dilakukan uji validitas konstruk integrasi sosial dengan menggunakan Confirmatory Factor Analysis (CFA) diperoleh model fit dengan chi-square $==1.23$, df $=3$ dan $\mathrm{p}$-value $==$ 0.74501 , RSMEA $=0.000$.

- Setelah dilakukan uji validitas konstruk kedekatan emosional dengan menggunakan Confirmatory Factor Analysis (CFA) diperoleh model fit dengan chi-square $==0.000, \mathrm{df}=0$ dan $\mathrm{p}$-value $=1.00000$, RSMEA $=0.000$.

- Setelah dilakukan uji validitas konstruk ikatan yang dapat diandalkan dengan menggunakan Confirmatory Factor Analysis (CFA) diperoleh model fit dengan chi-square $==0.000, \mathrm{df}=0$ dan p-value $=1.00000$, RSMEA $=0.000$.

- Setelah dilakukan uji validitas konstruk kemungkinan membantu dengan menggunakan Confirmatory Factor Analysis (CFA) diperoleh model fit dengan chi-square $==0.000, \mathrm{df}=0$ dan p- value $=1.00000$, RSMEA $=0.000$.

Tekhnik Analisa Data

Untuk melihat pengaruh independent variable yang diteliti yaitu religiusitas (keyakinan beragama, praktik ibadah, pengalaman beragama, pengetahuan beragama, konsekuensi beragama) dan dukungan sosial (bimbingan, penghargaan, integrasi sosial, kedekatan emosional, ikatan yang dapat diandalkan dan kemungkinan membantu) terhadap dependent variable yaitu kualitas hidup, peneliti menggunakan statistic analisis regresi berganda (multiple regression analysis).

\section{Hasil}

\section{Gambaran Deskriptif Sampel}

Pasien penderita kanker serviks RSCM yang dijadikan sampel sebanyak 130 dengan gambaran sebagai berikut : usia pasien kanker serviks yang paling banyak ditemukan pada usia 41-60 tahun dengan jumlah sebanyak $83.7 \%$, sedangkan untuk stadium didominasi oleh pasien kanker serviks stadium IIIB dengan prosentase sebanyak 51.5\% , Pada tingkat pendidikan ditemukan bahwa tingkat pendidikan merata dari yang tidak sekolah hingga tingkat perguruan tinggi menderita kanker 
serviks. Akan tetapi pada pasien dengan tingkat pendidikan SD sedikit lebih mendominasi dari keseluruhan dengan prosentase 34.6\%, Status pernikahan penderita kanker serviks didominasi dengan penderita yang berstatus menikah sebanyak $86.9 \%$, Kemudian untuk pekerjaan penderita kanker serviks didominasi dengan penderita yang bekerja sebagai ibu rumah tangga (IRT) sebanyak 73.8\%, Lalu didapat pula informasi bahwa skor kualitas hidup penderita kanker serviks adalah tinggi dengan prosentase $68.5 \%$

\section{Hasil Uji}

Langkah pertama peneliti melihat besaran R square untuk mengetahui berapa persen (\%) varians DV yang dijelaskan oleh IV seperti yang dijelaskan tabel 1.0 di bawah ini.

Tabel 1.0

Model Sumarry

R Square

\begin{tabular}{lrrrr}
\hline \multicolumn{5}{c}{ Adjusted $\mathrm{R}$} \\
Model & $R$ & R Square & Square & Std. Eroo of the Estimate \\
\hline 1 & $.563^{b}$ & .316 & .253 & 8.25662
\end{tabular}

Dari tabel, dapat dilihat bahwa diperoleh R-Square dengan nilai 0.316 atau sebesar $31.6 \%$, artinya proporsi varians dari kualitas hidup yang dijelaskan semua independent variable yaitu keyakinan, praktik ibadah, pengalaman, pengetahuan, konsekuensi, bimbingan, penghargaan, integrasi social, kedekatan emosi, ikatan yang diandalkan dan kemungkinan membantu adalah sebesar $31.6 \%$ sedangkan $68.4 \%$ sisanya dipengaruhi variabel lain diluar penelitian ini. Adapun hasil uji $\mathrm{F}$ dapat dilihat pada tabel 2.0 di bawah ini. 
Tabel 2.0

Anova pengaruh keseluruhan IV terhadap DV

\begin{tabular}{|c|c|c|c|c|c|c|}
\hline \multicolumn{2}{|c|}{ Model } & $\begin{array}{l}\text { Sum of } \\
\text { Squares }\end{array}$ & \multicolumn{2}{|r|}{ : } & $\mathrm{F}$ & Sigg, \\
\hline 1 & Regresvion & 3723.465 & 11 & 338.497 & 4965 & $.000^{2}$ \\
\hline & Residual & 8044.260 & 118 & 68.172 & & \\
\hline & $T+\infty \mathrm{d}$ & 11767.726 & 129 & & & \\
\hline
\end{tabular}

Dari tabel, dapat dilihat bahwa diperoleh R-Square dengan nilai 0.316 atau sebesar $31.6 \%$, artinya proporsi varians dari kualitas hidup yang dijelaskan semua independent variable yaitu mengatakan tidak terdapat pengaruh signifikan dari seluruh IV terhadap kualitas hidup ditolak. Artinya, terdapat pengaruh yang signifikan dari keyakinan, praktik ibadah, pengalaman, pengetahuan, konsekuensi, bimbingan, penghargaan, integrasi sosial, kedekatan emosi, kemungkinan membantu dan ikatan yang dapat diandalkan terhadap kualitas hidup pada pasien kanker serviks RSCM.

Langkah terakhir adalah melihat koefisien regresi tiap independent variable. Jika nilai Sig. $<0.05$ maka koefisien regresi tersebut signifikan yang berarti bahwa IV tersebut memiliki dampak yang signifikan terhadap burnout. Adapun penyajiannya pada tabel 3.0 berikut:

Tabel 3.0

Koefisien Regresi

Coefficients $^{\mathrm{a}}$

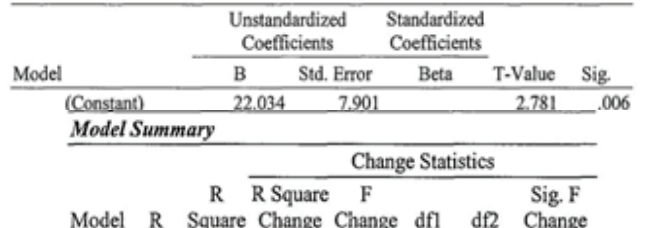

\begin{tabular}{lrrrrrrr} 
Model & $\mathrm{R}$ & Square Change Change & df1 & df2 & Change \\
\hline 1 & $.163^{\mathrm{a}}$ & .027 & .027 & 3.494 & 1 & 128 & .064
\end{tabular}

$\begin{array}{llllllll}2 & .286^{\mathrm{b}} & .082 & .055 & 7.626 & 1 & 127 & .007\end{array}$

$\begin{array}{llllllll}3 & .449^{6} & .201 & .120 & 18.900 & 1 & 126 & .000\end{array}$

$\begin{array}{llllllll}4 & .470^{4} & .221 & .020 & 3.139 & 1 & 125 & .179\end{array}$

$\begin{array}{llllllll}5 & .486^{\circ} & .236 & .015 & 2.506 & 1 & 124 & .116\end{array}$

$\begin{array}{llllllll}6 & .538^{f} & .289 & .053 & 9.096 & 1 & 123 & .003\end{array}$

$\begin{array}{llllllll}7 & .547^{\star} & .299 & .010 & 1.796 & 1 & 122 & .183\end{array}$

$\begin{array}{lllllllll}8 & .548^{\mathrm{b}} & .301 & .001 & .198 & 1 & 121 & .657\end{array}$

$\begin{array}{llllllll}9 & .550^{i} & .302 & .002 & .330 & 1 & 120 & .567\end{array}$

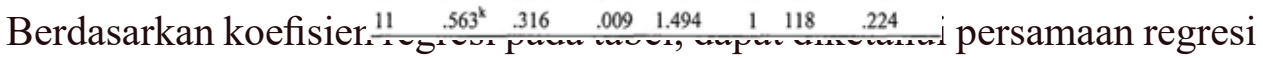
sebagai berikut: 
Kualitas Hidup $=22.034-0.300$ Keyakinan -0.040

Praktik Ibadah +0.515 Pengalaman +0.144

Pengetahuan -0.210 Konsekuensi +0.282

Bimbingan +0.100 Penghargaan -0.049

Integrasi Sosial -0.163 Kedekatan Emosi +0.116

Kemungkinan Membantu +0.165 Ikatan yang dapat diandalkan.

Dapat dilihat bahwa hanya koefisien regresi tidak ada variabel yang signifikan. Hal ini berarti dari 11 hipotesis minor terdapat hipotesis yang signifikan yaitu pada variabel penghargaan dan pengalaman. Penjelasan dari nilai regresi yang diperoleh masing-masing IV adalah sebagai berikut:

1. Dimensi Keyakinan

Diperoleh nilai regresi sebesar -0.300 dengan signifikansi 0.019 (sig < 0.05). Hal ini menunjukkan bahwa variabel Keyakinan pada Religiusitas mempengaruhi secara negatif dan signifikan terhadap Kualitas hidup, artinya semakin tinggi keyakinan maka semakin rendah kualitas hidup.

2. Dimensi Praktik Ibadah

Diperoleh nilai regresi sebesar-0.040 dengan signifikansi 0.727 (sig $>0.05$ ). Hal ini menunjukkan bahwa variabel Praktik Ibadah pada Religiusitas tidak mempengaruhi secara signifikan terhadap Kualitas Hidup.

3. Dimensi Pengalaman

Diperoleh nilai regresi sebesar 0.515 dengan signifikansi 0.001 (sig $<0.05$ ). Hal ini menunjukkan bahwa variabel Pengalaman pada Religiusitas mempengaruhi secara signifikan terhadap Kualitas Hidup. Artinya semakin tinggi pengalaman maka semakin tinggi pula kualitas hidup.

4. Dimensi Pengetahuan

Diperoleh nilai regresi sebesar 0.144 dengan signifikansi 0.474 (sig $>0.05$ ). Hal ini menunjukkan bahwa variabel Pengetahuan pada Religiusitas tidak mempengaruhi secara signifikan terhadap Kualitas Hidup.

5. Dimensi Konsekuensi

Diperoleh nilai regresi sebesar -0.210 dengan signifikansi 0.053 (sig $>0.05$ ). Hal ini menunjukkan bahwa variabel Konsekuensi pada Religiusitas tidak mempengaruhi secara signifikan terhadap Kualitas Hidup.

6. Dimensi Bimbingan

Diperoleh nilai regresi sebesar 0.282 dengan signifikansi 0.292 (sig $>0.05$ ). Hal ini menunjukkan bahwa variabel Bimbingan pada Dukungan Sosial tidak mempengaruhi secara signifikan terhadap 
Kualitas Hidup.

7. Dimensi Penghargaan

Diperoleh nilai regresi sebesar 0.100 dengan signifikansi 0.436 (sig $>0.05$ ). hal ini menunjukkan bahwa variabel penghargaan tidak berpengaruh secara signifikan pada dukungan sosial terhadap Kualitas Hidup.

8. Dimensi jenis Integrasi Sosial

Diperoleh nilai regresi sebesar -0.049 dengan signifikansi 0.537 (sig $>0.05$ ). Hal ini menunjukkan bahwa variabel integrasi sosial tidak berpengaruh secara signifikan pada dukungan sosial terhadap kualitas hidup.

9. Dimensi Kedekatan Emosi

Diperoleh nilai regresi sebesar -0.163 dengan signifikansi 0.490 (sig > 0.05). Hal ini menunjukkan bahwa variabel Kedekatan Emosi tidak berpengaruh secara signifikan pada dukungan sosial terhadap Kualitas Hidup.

10. Dimensi Kemungkinan

Membantu Diperoleh nilai regresi sebesar 0.116 dengan signifikansi 0.467 (sig > 0.05). Hal ini menunjukkan bahwa variabel kemungkinan membantu tidak berpengaruh secara signifikan pada dukungan sosial terhadap Kualitas Hidup.

11. Dimensi Ikatan yang dapat diandalkan

Diperoleh nilai regresi sebesar 0.165 dengan signifikansi 0.224 (sig $<0.05$ ). Hal ini menunjukkan bahwa variabel Ikatan yang diandalkan berpengaruh secara signifikan pada dukungan sosial terhadap kualitas hidup.

Tabel 4.0

Proporsi Varian Dependent Variabel yang Disebabkan Masing-masing Varian Independen Variabel

Dari tabel, dapat disampaikan informasi sebagai berikut: 
1. Dimensi Keyakinan memberikan sumbangan sebesar $0.27 \%$ dalam Kualitas Hidup. Sumbangan tersebut tidak signifikan secara statistik dengan $\mathrm{F}=0.064$ dan $\mathrm{df}=1,128(\mathrm{sig}>0.05)$.

2. Dimensi Praktik Ibadah memberikan sumbangan sebesar $0.55 \%$ dalam Kualitas Hidup. Sumbangan tersebut signifikan secara statistik dengan $\mathrm{F}=0.007$ dan $\mathrm{df}=1,127(\operatorname{sig}<0.05)$.

3. Dimensi Pengalaman memberikan sumbangan sebesar $1.20 \%$ dalam Kualitas Hidup. Sumbangan tersebut signifikan secara statistik dengan $\mathrm{F}=$ 0.000 dan $\mathrm{df}=1,126(\mathrm{sig}<0.05)$.

4. Dimensi Pengetahuan memberikan sumbangan sebesar $0.20 \%$ dalam Kualitas Hidup. Sumbangan tersebut tidak signifikan secara statistik dengan $\mathrm{F}=0.179$ dan $\mathrm{df}=1,125$ ( $\mathrm{sig}>0.05)$.

5. Dimensi Konsekuensi memberikan sumbangan sebesar $0.15 \%$ dalam Kualitas Hidup. Sumbangan tersebut tidak signifikan secara statistik dengan $\mathrm{F}=0.116$ dan $\mathrm{df}=1,24(\mathrm{sig}>0.05)$.

6. Dimensi Bimbingan memberikan sumbangan sebesar $0.53 \%$ dalam Kualitas Hidup. Sumbangan tersebut signifikan secara statistik dengan $\mathrm{F}=$ 0.003 dan $\mathrm{df}=1,123(\mathrm{sig}<0.05)$.

7. Variabel Penghargaan memberikan sumbangan sebesar $0.10 \%$ dalam Kualitas Hidup. Sumbangan tersebut tidak signifikan secara statistik dengan $\mathrm{F}=0.183$ dan $\mathrm{df}=1,122(\mathrm{sig}>0.05)$

8. Variabel Integrasi Sosial memberikan sumbangan sebesar $0.01 \%$ dalam Kualitas Hidup. Sumbangan tersebut tidak signifikan secara statistik dengan $\mathrm{F}=0.657 \mathrm{dan} \mathrm{df}=1,121(\mathrm{sig}>0.05)$

9. Variabel Kedekatan Emosi memberikan sumbangan sebesar $0.02 \%$ dalam Kualitas Hidup. Sumbangan tersebut tidak signifikan secara statistik dengan $\mathrm{F}=0.567 \mathrm{dan} \mathrm{df}=1,120(\mathrm{sig}>0.05)$

10. Variabel Kemungkinan Membantu memberikan sumbangan sebesar $0.05 \%$ dalam Kualitas Hidup. Sumbangan tersebut tidak signifikan secara statistik dengan $\mathrm{F}=0.340$ dan $\mathrm{df}=1,119(\mathrm{sig}>0.05)$

11. Variabel Ikatan yang dapat diandalkan memberikan sumbangan sebesar $0.09 \%$ dalam Kualitas Hidup. Sumbangan tersebut tidak signifikan secara statistik dengan $\mathrm{F}=0.224$ dan $\mathrm{df}=1,155(\mathrm{sig}>0.05)$

\section{Diskusi}

Penelitian ini merupakan usaha untuk lebihmemahami konteks variabel internal yang ada dalam diri individu penderita kanker serviks dalam mempengaruhi kualitas hidupnya. Hasil dari penelitian ini yaitu terdapat pengaruh signifikan pada variabel religiusitas dan dukungan sosial terhadap kualitas hidup penderita kanker serviks. Hal ini sejalan dengan penelitian oleh Zeng et al. (2010) yang menemukan penderita kanker serviks di China mendapatkan kualitas hidup dari status sosial ekonomi yang baik, aspek 
spiritualitas ataupun religiusitas yang baik dan dukungan sosial yang baik pula (Zeng. et al.,2010)

Pada penelitian ini variabelyang memiliki pengaruh signifikan terhadap kualitas hidup adalah religiusitas pada dimensi pengalaman, keyakinan dan konsekuensi. Dimensi pengalaman memiliki pengaruh yang positif terhadap kualitas hidup. Artinya, semakin tinggi pengalaman keberagamaan seseorang melalui apa yang telah ia rasakan maka akan semakin tinggi pula kualitas hidupnya. Hal ini sejalan dengan penelitian Klass \& Gordon (1978) yang menyatakan bahwa sikap transendental dapat mentransformasi diri manusia menjadi transformasi yang positif sehingga seseorang mampu menerima kehidupannya dan bertahan (Kaye \& Raghavan, 2002)

Pada dimensi keyakinan memiliki pengaruh yang negatif terhadap kualitas hidup, artinya semakin tinggi keyakinan keberagamaan seseorang maka semakin rendah kualitas hidupnya. Hal ini tidak sejalan dengan penelitian Aukust (2009) bahwa religiusitas yang tinggi mampu mempengaruhi kualitas hidup dan persepsi kesehatan penderita kanker payudara (Aukst, et al., 2009)

Begitu juga halnya dengan dimensi konsekuensi. Pada dimensi ini memiliki pngaruh yang negatif. Artinya, semakin tinggi konsekuensi keberagamaan seseorang maka semakin rendah kualitas hidupnya. Hal ini juga tidak sejalan dengan penelitian Aukust (2009) bahwa religiusitas yang tinggi mampu mempengaruhi kualitas hidup penderita kanker payudara (Aukst. et al., 2009)

Asumsi terhadap dimensi keyakinan dan konsekuensi yang tidak memiliki pengaruh positif terhadap kualitas hidup adalah dimungkinkan bahwa religisitas pada dimensi keyakinan dan konsekuensi tidak signifikan bagi penderita kanker serviks di RSCM. Dimungkinkan dengan memiliki keyakinan yang tinggi bahwa Tuhan maha pengasih dan penyayang tetapi justru Tuhan memberikan sakit yang tak kunjung sembuh. Demikian pula dengan dimensi konsekuensi, yang memberikan keyakinan bahwa jika melakukan hal baik tentu akan ada balasan yang baik pula untuknya tetapi ia malah diberikan sakit. Kondisi ini justru mematahkan harapannya sehingga menurunkan persepsi kualitas hidupnya. Berbeda dengan dimensi pengalaman, ketika ia merasa Tuhan akan menolongnya mengangkat sakitnya dan hal itu terjadi pada dirinya maka kualitas hidupnya pun meningkat. Disamping itu, peneliti memiliki kekurangan dalam penelitian ini yaitu peneliti kurang menggali data rentang waktu berapa lama penderita menderita kanker serviks sehingga peneliti tidak memiliki data penderita kanker serviks sedang menjalani fase apa dalam menjalani kehidupannya. Apakah ia sedang dalam fase baru menerima vonis kanker serviks atau sudah dalam fase menjalani pengobatan kanker serviks. Hal tersebut diasumsikan juga bisa menjadi faktor yang menyebabkan dimensi keyakinan dan konsekuensi pada variabel religiuisitas memiliki pengaruh yang negatif terhadap kualitas hidup penderita kanker serviks. 
Pada variabel dukungan sosial, ternyata variabel ini tidak memiliki pengaruh yang signifikan terhadap kualitas hidup.

\section{Saran}

Bagi keluarga pasien, peneliti menyarankan untuk dapat meningkatkan aspek religiusitas terutama pada pengalaman keberagamaan pasien dan memberikan dukungan serta semangat untuk kesembuhan pasien. Interaksi sosial dan dukungan dari orang-orang terdekat sangat dibutuhkan oleh pasien.

Terkait saran untuk pihak rumah sakit, ataupun lembaga-lembaga kesehatan lainnya diharapkan memberikan penyuluhan dan memberikan pengertian kepada masyarakat bahwa pentingnya meningkatkan aspek religiusitas pasien khususnya pada dimensi pengalaman keberagamaan dan menyediakan sarana di rumah sakit yang berkaitan dengan peningkatan aspek religiusitas khususnya pada pengalaman keberagamaan pasien.

\section{Referensi}

American Cancer Society. (2013). Cervical cancer : Prevention and early detection. Diunduh tanggal 20 juni 2014

Ancok, D., \& Suroso, F.N. (1994). Psikologi Islami. Yogyakarta: Pustaka Pelajar

Banett, S.J., Perkins, S.M., Lane, K.A., Deer., Brater, D.C., \& Murray, M.D. (2001). Social Support and Health- related Quality of Life in chronic hearth failure patients. QOL Research. 10, 671-682.

DHCS. (2013). Kanker Serviks- Departement of Health Care Service. Diunduh tanggal 12 agustus 2013 dari http://dhcs.ca.gov/.../2013-

0603_web_cancer-of-the- cervix_indo-pdf

Durkheim, Emile. (2003). Sejarah agama. Yogyakarta: IRCiSoD

Fitriana, N, A., \& Ambarini, T, K. (2012). Kualitas hidup pada penderita Kanker serviks yang menjalani pengobatan radioterapi. Jurnal Psikologi Klinis dan Kesehatan Mental Universitas Airlangga. Fakultas Psikologi Universitas Airlangga: Surabaya 1 (2), 1-10.

Frank, G.F., Mitchell, R., \& Caplan, B. (2010). Handbook rehabilitation psychology. Washington DC: APA.

Glock, C.Y., \& Stark, R. (1968). American piety: The Nature of Religious 
Comitment. London: University of California

Jalaluddin.(1996). Psikologi agama. Jakarta: PT Raja Grafindo Persada

Kaye, J., Raghavan. S.K. (2002). Spirituality in disability and illness. 41 (3), 231-242

Kemenkes (2008). Program kesehatan reproduksi dan pelayanan integratif di tingkat pelayanan dasar. Diunduh tanggal 15 November 2013 dari http:// bkmbkidepkes.go.id

KemenkesRI (2009). Buku saku kanker. Diunduh tanggal 29 Juni 2013 dari http://pppldepkes.go.id

Kemp Henderson, K.Y. (2011). Race in diferrences religiousity, social support and quality of life among people living with HIV/AIDS in Dallas/FT Worth. TX. Texas : University of Texas

Kerlinger, F.N. (2004). Asas-asas penelitian behavioral. Yogyakarta: Gajah Mada University Press

Kim, H.S., Sherman, D.K., \& Taylor, S.E. (2008). Culture and social support. Journal American Psychological Association, 63 (6), 518-526

Lauer, R.H \& Lauer, C.J (2004). Social problems and the quality of life. United State : Mc Graw Hill

Lim, J,W., \& Jaehee, Y. (2009). The effect of religiousity, spirituality and social support on quality of life : a comparison between Korean American and Korean breast and gynecologic cancer survivor. Journal Oncology Nursing Forum, 36 (6), 232-245

Margetic, B.A., Jakovljevic, M., Ivance, D., Margetic, L.D., \& Samija, M. (2009). Religiousity and QOL. Journal Coll. Antropoll. 33 (4), 1265-1271

Marvin,. Guay, D., Hui, D., Parsons, H.A., Govan, K., De la C, M ., Thorney, S., Bruera, E. (2011). Spirituality, religiousity and spiritual pain in advanced cancer patients. Journal of pain and symptom management, 41 (6), 25-44.

Orford, Jim. (1992). Community psychology theory and practice. Library of Congress Catalogig- Publication Data: Great Britain 
Russell, D.W., Cutrona, C.E. (1987). The provisions of social relationship and adaptation to stress. Advances in personal relationship, 1, 37-67

Safarino, E.P. (1990). Health psychology biopsycosocial interactions. New York : State College

Schalok, R.L., Brown, I., Brown, R., Cummins, R.A., David,F., Matikka,L., Keith, K.D., \& Parmenter, T. (2002). Conceptualization, measurement, and application of quality of life for persons with intellectual disabilities: report of an international panel of experts. Journal Mental Retardation 40 (6), 457470

Smet, B (1994). Psikologi kesehatan. Jakarta : PT Grasindo

Taylor, Shelley.E. (2009). Health psychology.California: Mc Graw Hill

Visser, M.R.M., \& Smets, E.M.A. (1998). Fatigue, depression and quality of life in cancer patients. Journal Support Care Cancer 6, 101-108

WALQING WORK PAPER (2011). Quality of life in Europe. Diunduh dari http://walqing.eu pada tanggal 15 November 2013

WHO (2013). Sexual \& reproductive health comprehensive cervical cancer prevention \& control : healthier future for girls and women. Diunduh tanggal 11 november 2013 dari http://who.int/reproductivehealth/ top ics/cancer/en/

WHO (2004). WHOQOL-BREFF. Diunduh dari www.who.int pada 30 juni 2013

WHOQOL User Manual (2012) diunduh dari www.who.int pada 30 Juni 2013

WHO (2013). Why the time is right to tackle breast and cervical cancer in low resource setting. Bulletin of the World Health Organization, 91, 683-690.

Diunduh tanggal 11 oktober 2013 dari http://dx.doi.org/10.2471/BLT.12.116020 